\title{
The application of probability theory in speculative game of stock market
}

\author{
Ya GuoLiu ${ }^{1, \text { a }}$ \\ ${ }^{1}$ Heyuan vocational and technical college, Heyuan, Guangdong, China
}

\begin{abstract}
The main fact of China's stock market so far is that it is a policy market, a capital driven market and a speculative market. Value investment is scarce. This paper tries to use the method of probability theory to get rid of the fog of the market, help the majority of retail investors wake up in cognition, realize that the strong are always strong, and form their own investment style, so as to realize the stable profit from the market.
\end{abstract}

\section{The current situation of China's stock market}

\subsection{Why is it so difficult to make money in Chinesestockmarket}

Because there is too little capital in the market (most of the wealth of Chinese residents is in the property market), especially in bear and volatile markets, there will be less capital entering the stock market. Because the amount of funds is too small, institutions or hot money can only guide and drive some retail funds to show partial profit effect in a very small number of stocks. This is why the market is often the root of the structural market, and also doomed to the short bull market and long bear market pattern in China's stock market. Because of the small amount of capital in the market, the fluctuation of the market will be very big, so the specific performance is in the high turnover rate, the volatility of the stock index, the abnormal change of trading volume, and the sharp rise and fall of individual stock market.[1]

Table 1: turnover rate of stock markets in major cities from 1997 to 2019

\begin{tabular}{|c|c|c|c|c|}
\hline City & Shanghai & Shenzhen & $\begin{array}{c}\text { New } \\
\text { York }\end{array}$ & Tokyo \\
\hline $\begin{array}{c}\text { Annual } \\
\text { turnover } \\
\text { rate }\end{array}$ & 412.7 & 426.9 & 52.8 & 25.2 \\
\hline City & $\begin{array}{c}\text { Hong } \\
\text { Kong }\end{array}$ & London & Singapore & Thailand \\
\hline $\begin{array}{c}\text { Annual } \\
\text { turnover } \\
\text { rate }\end{array}$ & 69.7 & 67.4 & 32.6 & 78.2 \\
\hline
\end{tabular}

Turnover rate refers to the ratio between the number of shares traded and the number of shares in circulation, that is, the turnover rate $=$ the number of shares traded / the number of shares in circulation x $100 \%$. If the stock is traded, there will be turnover rate, but the turnover rate in China is too high. Table 1 shows the turnover rate of stock markets in major cities in the world. The turnover rate of Shanghai and Shenzhen stock markets is much higher than that of other ticket markets in the world. The high turnover rate and big market fluctuation mean that the risk of investing in China's stock market is huge.

In China's A-share market, it is difficult for retail investors to make a living in this market if they do not have a quiet heart, a pair of sharp eagle eyes, and a comprehensive system of cognition, technology and mental method suitable for the survival of the stock market. Let's use probability to dispel the fog of the stock market.[2]

\subsection{Only $5 \%$ can win}

In 2001, economist Wu Jinglian once said on CCTV: China's stock market is not even a standard gambling house. [3] One language shows the essential characteristics of China's a shares. People often say that a shares are 7 losses, 2 breakeven and 1 profit. I feel that this formulation is problematic. According to what I have seen and identified, only about $5 \%$ of the A-shares can make money, and $95 \%$ of them are losing money, and they are continuously losing money. There is no "breakeven" in the stock market, because buying stocks takes up funds. If funds have opportunities and time costs, the annual currency overspread proves that the so-called "breakeven" is actually a loss.

No doubt, I found that only $5 \%$ of the A-share market can make money, and it is a huge profit. The reason is very simple. $95 \%$ of the people are losing money. Who is losing so much money to? Part of the money lost was taken away by the trading fees of the securities companies, part was taken away by the state stamp duty, part was evaporated by the rise and fall of individual stocks, and part was taken away by $5 \%$ of the smart

aemail: 29395172@qq.com 
players in the stock market.

Because the stock market does not create wealth, the stock market only transfers wealth.

So, the $5 \%$ that can make money is just because of good luck, or is it really because the stock market is highly skilled and controls the laws of the stock market? To put it another way, that is, how the $5 \%$ people who make money are formed. It is very important to understand this issue.

Well, let's express a problem. Suppose there are 100 stock speculators here.

The first situation: these five people make money this year, and those five people make money next year.

The second situation: it's the five people who make money this year, and it's the five people who make money next year.

The correct conclusion is: in the second case, that is, $5 \%$ of the people can make money, not because of his good luck, but because he has found out the true meaning of the stock and is lucky to become the very few people who can make steady profits.

\section{The application of probability in stock market game}

\subsection{In the stock market, ten operations and four profits are enough. The profit ratio is more important than the winning ratio}

For a long time, the pursuit of high success rate (operation success rate) is a common fault of the majority of shareholders. Maybe the stock experts in their hearts should be stable. However, there is no God in the stock market and it is impossible to make profits immediately after every transaction. Therefore, the stock market profit itself is a probability problem.

Generally speaking, 10 operations, as long as the success of 4 times, failure 6 times, often can also earn a little.

Why? It seems that the success rate is only $40 \%, 20 \%$ lower than $60 \%$ of 10 operations, 6 successes and 4 failures. In fact, it is not the case. If the four times of success make more than $7 \%$ each time, the profit will be $28 \%$, and the six times of failure, the loss will be $4 \%$ each time, and the total loss will be $24 \%$. In this way, there will be about $4 \%$ of the income. If 10 transactions can make $4 \%$ profit, it is already quite considerable. The interest rate of a year deposited by the bank is less than $2 \%$. However, for 10 operations, 6 times of success and 4 times of failure, money may also be lost. If the 6 times of success make $3 \%$ each time, they will run away with only $18 \%$ profit. If the four times of failure, they will lose $6 \%$ and then cut the meat, and lose $24 \%$, can we calculate whether the loss is still $6 \%$.

How much can each successful profitable stock operation earn? This is called earning ratio. Generally speaking, when you want to buy a stock, you have to ask yourself, will the stock yield reach $7 \%$ ? Will it reach $10 \%$ ? Will it reach $15 \%$ ? If you are only aiming to earn $3 \%$ in this stock operation, it is very dangerous and not worth the risk. Therefore, in your investment system, stable earnings ratio is the key.

\subsection{Three consecutive days of losses, the fourth day to earn more hope?}

In 1906, Russian mathematician aamarisov proposed Markov chain, which is a discrete sequence stochastic process with Markov property in mathematics. In this process, given the current information, the past (that is, the historical state before the current) is irrelevant to the prediction of the future (that is, the future state after the current). [4]

Professionally speaking, it is:

$$
\begin{gathered}
P\left(X_{n+1}=x \mid X_{1}=x_{1}, X_{2}=x_{2}, \ldots \ldots, X_{n}=x_{n}\right) \\
=P\left(X_{n+1}=x \mid X_{n}=x_{n}\right)
\end{gathered}
$$

The discrete sequence $X_{1}, X_{2}, X_{3} \ldots \ldots X_{n}$ satisfying the conditional probability equation has Markov property.

To put it simply, if the present is given, the future is not affected by the past.

The nature of Markov is different from a deck of playing cards. When someone else holds a small card, you can catch a big card.

In stock investment, will the probability of first day loss, second day loss, third day loss and fourth day profit increase? The answer is: the probability of making a profit on the fourth day is not affected by the previous three days.

Individual stocks: today's rise, tomorrow's rise, and the day after tomorrow's rise, so big is the probability of falling the day after tomorrow? The answer is: in theory, the probability of the day after tomorrow will not increase. On the contrary, in practice, the probability of the day after tomorrow will increase.

Therefore, people who have suffered losses in the stock market like to copy the bottom. They fall today, fall tomorrow, and fall the day after tomorrow. They have been falling for nearly a month. They think they are almost at the bottom. As a result, they copy the bottom on the hillside.

Of course, stock investment can not be simply abstracted into a Markov chain. In fact, the discrete series in stock investment are related, not independent. I think it is closer to a time series analysis, similar to the weather forecast in daily life.

\subsection{Conditional probability and mathematical expectation}

In A-share market, every day's stock operation is a continuous recurrence of conditional probability.

Conditional probability: the probability of occurrence of event $\mathrm{A}$ under the condition that event $\mathrm{B}$ has occurred, which is called conditional probability, Mark it as $\mathrm{P}(\mathrm{A} \mid \mathrm{B})$, Read it as "the probability of A under B", If there are only two events $\mathrm{A}$ and $\mathrm{B}$, then,

$$
\mathrm{P}(\mathrm{A} \mid \mathrm{B})=\frac{\mathrm{P}(\mathrm{AB})}{\mathrm{P}(\mathrm{B})}
$$

$\mathrm{P}(\mathrm{AB})$ is the probability that event $\mathrm{A}$ and event $\mathrm{B}$ occur simultaneously. If $A$ and $B$ are independent events, then, $\mathrm{P}(\mathrm{AB})=\mathrm{P}(\mathrm{A}) \mathrm{P}(\mathrm{B}) \cdot[5]$ 
Example 1: there are many independent events in reality, such as giving birth to a child. $\mathrm{P}$ (the probability of having a boy in this birth | a girl in the last birth)= $\mathrm{P}$ (the probability of giving birth to a boy in this baby) means that the probability of a boy born in the last birth will not change (not increase or decrease).

Example 2: the probability of a stock rising the next day is 0.45 , which is recorded as $\mathrm{P}$ (up) $=0.45$. Now the conditions change. Tonight, it is announced that it intends to acquire high-quality assets. Then the conditional probability $\mathrm{p}$ (up | planned acquisition) $>>0.45$, which may reach 0.9 and 0.95 .

Mathematical expectation: the sum of the product of all possible values $\mathrm{Xi}$ and the corresponding probability $\mathrm{Pi}$ of a discrete random variable is called the mathematical expectation of the discrete random variable. Mathematical expectation is generally understood as the average.

$$
E(X)=\sum_{i=1}^{n}\left(x_{i} p_{i}\right)
$$

If someone likes to chase the limit up, i.e. buying at $10 \%$ position, the day is not profitable, and the next day is profitable, assuming that the probability of success of someone chasing the trading limit board is 0.7 (success is that only the closing of the day can seal the trading limit board), the probability of failure is 0.3 , the average profit in the case of success is $\mathrm{A} \%$, and the average loss in the case of failure is $\mathrm{B} \%$.

Then the mathematical expectation of return $\mathrm{x}$ is $\mathrm{EX}=\mathrm{A} \% \times 0.7+(-\mathrm{B} \%) \times 0.3$

If $A=3, B=5$

Then $\mathrm{EX}=3 \% \times 0.7+(-5 \%) \times 0.3=0.6 \%$

If $\mathrm{A}=3, \mathrm{~B}=3$, then $\mathrm{EX}=1.2 \%$

Judging from this, there is still potential to pursue the limit up. At least from the perspective of probability, as long as the number of operations is enough, the profit will gradually accumulate. In fact, four years of ten times, 100 times of hot money is the practice of this model.

\subsection{Today's trading limit stock, tomorrow's trading limit probability?}

Let's talk about the limit up again.

If the probability of a stock limit up is $1 \%$, then the probability of trading the next day is $1 \%$ ?

There are 3800 stocks in the two cities. If there are 38 trading limits in one day, if we assume that the probability of a stock's trading limit is $1 \%$, then is the probability of this stock going up and down again the next day still $1 \%$ ?

We have noticed that some people in the market liketo buy the stock on the next day of the stock price limit up. What is the winning rate of this trading mode and whether there is a probability basis.

In fact, if four of the 38 stocks in today's trading limit are trading in the next day, we can conclude that the probability of trading in the next day is $10 \%$, not $1 \%$, that is, the probability of trading in the next day is 10 times higher than we expected.

This is a conditional probability. Under this condition, the sample space studied and analyzed has also changed, and the sample space has been reduced from 3800 to 38 .

For example, if an athlete wins a gold medal, he is more likely to win a second one. If a teacher takes a scientific research project, it will be easier for him to get the next one.

Of course, our assumption is flawed. We assume that the probability of each stock's trading limit is the same. This is an equal probability model in the classical probability model. This assumption does nothold. This is like to say that the probability of zhongqingbaotrading limit is the same as that of PetroChina. How ridiculous. Stocks such as high school entrance examination enrollment rate, read some famous high school, one foot has entered Peking University, some ordinary high school dream of university is difficult.

Every stock is born with a different probability of trading. Generally speaking, small cap stocks are more likely to rise than large cap stocks, and Shenzhen GEM is more likely to rise than Shanghai main board. That means that the "limit gene" of each stock is different. We can also say that the activity of a stock is different. We can measure the activity of a stock by compiling a simple and useful process. For example, in 90 trading days of three months, the number of items with an increase of more than $8 \%$, the larger the number, the more active. Therefore, when we buy stocks, we should buy stocks with good properties, that is, active stocks.

If the increase is large, it will continue to rise, and the rich will get richer. This is the so-called Matthew effect.

Matthew effect refers to the phenomenon that the strong are always strong and the weak are weak. It is widely used in education, finance, social psychology and other fields. Matthew effect is a professional term commonly used by sociologists and economists. It reflects the social phenomenon of polarization. The rich are richer and the poor are poorer. It is a very important law of human society.

Laozi in ancient China said:"the way of heaven is to use the rich to help the poor. The way of human being is not the same. It is use the poor to subsidize the rich"

\subsection{Great significance of long term stable compound interest}

With regard to compound interest, assuming that the principal is 10000 yuan, if the long-term stable monthly profit of $\mathrm{a} \%$ can be achieved, the income in the next few years can be calculated as follows:

$$
\mathrm{b}=1 \times(1+\mathrm{a} \%)^{\mathrm{n}}
$$

For example, if the monthly stable income is $10 \%$, after the first year, $1 \times(1+10 \%)^{12}=3.14$, then the fund will be $10000 \times 3.14=31400$ yuan..

Therefore, we can list them in tables. 
Table 2: stable profit and income statement (with 2 decimal places reserved)

\begin{tabular}{|c|c|c|c|}
\hline \multirow{2}{*}{$\begin{array}{c}\text { Average } \\
\text { monthly } \\
\text { income }\end{array}$} & \multicolumn{3}{|c|}{ Years } \\
\cline { 2 - 4 } & $\begin{array}{c}\text { After the first } \\
\text { year(times) }\end{array}$ & $\begin{array}{c}\text { After the second } \\
\text { year(times) }\end{array}$ & $\begin{array}{c}\text { After the third } \\
\text { year(times) }\end{array}$ \\
\hline $\begin{array}{c}\text { Stable income } \\
10 \% \text { per month }\end{array}$ & 3.14 & 9.85 & 30.91 \\
\hline $\begin{array}{c}\text { Stable income } \\
20 \% \text { per month }\end{array}$ & 8.92 & 79.50 & 708.80 \\
\hline $\begin{array}{c}\text { Stable income } \\
30 \% \text { per month }\end{array}$ & 23.30 & 542.80 & 12646.22 \\
\hline
\end{tabular}

See the power of compound interest? As long as we can make a steady profit and make $30 \%$ of the monthly income, we can achieve more than 10000 times in three years. In reality, of course, it is almost impossible. As long as we can make a stable profit, even if the monthly income is much less than $30 \%$, the final total income will be very considerable over time (such as 10 years). As mentioned above, don't underestimate the $1.2 \%$ profit. In the long run, the profit is not poor. In reality, many hot money started from trading limit board, which is the power of compound interest.

Of course, after the funds reach a certain scale, it is impossible to increase the compound interest. Small capital needs to fight hard, and large capital needs to be stable.

\section{3 conclusion}

Stock investment is the lowest threshold of all investment and the most difficult business to make money. The iron law of the stock market is that some people make money because someone loses money. The stock market is not a treasure house for creating value, but a place for redistribution of wealth and interests. The success of the stock market is not so simple. The purpose of clearing the fog and seeing the truth is to wake up in the stock market. Only when we wake up in the market, have a glimpse of the essence of the stock market, and have an epiphany of the stock market, can we have the capital to compete with the excellent falcons in the stock market where you die or I live, and not become the prey of the falcons.

\section{References}

1. $\mathrm{Hu}$ en Tong: (2002) analysis of stock market speculation game, Journal of Anyang University, No.1, 2002: 14-15

2. XuYiguang: (2003) good news beckoning China stock market, global finance, 2003, issue 7: 76-78

3. Wu Jinglian: (2001) ten years of controversy on the stock market, Shanghai Far East publishing house, Beijing

4. He xuansen. (2009) stochastic process, people's post and Telecommunications Press, Beijing

5. Sheng Ju, XieShiqian, pan Chengyi. (2008) probability theory and mathematical statistics (Fourth Edition), higher education press, Beijing 